NBER WORKING PAPER SERIES

\title{
REGULATION OF ENTRY AND THE DISTORTION OF INDUSTRIAL ORGANIZATION
}

\author{
Raymond Fisman \\ Virginia Sarria-Allende \\ Working Paper 10929 \\ http://www.nber.org/papers/w10929 \\ NATIONAL BUREAU OF ECONOMIC RESEARCH \\ 1050 Massachusetts Avenue \\ Cambridge, MA 02138 \\ November 2004
}

The views expressed herein are those of the author(s) and do not necessarily reflect the views of the National Bureau of Economic Research.

(C) 2004 by Raymond Fisman and Virginia Sarria-Allende. All rights reserved. Short sections of text, not to exceed two paragraphs, may be quoted without explicit permission provided that full credit, including $\odot$ notice, is given to the source. 
Regulation of Entry and the Distortion of Industrial Organization

Raymond Fisman and Virginia Sarria-Allende

NBER Working Paper No. 10929

November 2004

JEL No. O14, K2, L11

\begin{abstract}
$\underline{\text { ABSTRACT }}$
We study the distortions to industrial organization caused by entry regulation. We take advantage of heterogeneity across industries in their natural barriers and growth opportunities to examine whether some industries are differentially affected by country-level entry regulation. In industries with high natural entry barriers, entry regulation has little impact on the quantity and average size of firms in an industry. By contrast, in industries with low natural entry barriers, countries with high entry regulation have relatively few, large firms. We find no relation between natural entry barriers and overall industry share of manufacturing, as a function of entry regulation. Utilizing firm-level data, we show that operating margins are relatively high in low barrier industries in high entry regulation countries. Finally, we analyze the ability of industries to take advantage of shocks to growth opportunities. In countries with high entry regulation, industries respond to growth opportunities through the expansion of existing firms, while in countries with low entry regulation, the response is through the creation of new firms; the total sectoral response is invariant to the level of regulation. Our results suggest that regulation distorts the structure of industry, promoting industry concentration, but does not have measurable effects on intersectoral allocations.

Raymond Fisman

Uris 823

Graduate School of Business

Columbia University

3022 Broadway

New York, NY 10027

and NBER

rf250@columbia.edu

Virginia Sarria-Allende

vsarria@iae.edu.ar
\end{abstract}


Economists have presented two contrasting views of government regulation of economic activity. Under the Public Choice view (Stigler (1971), regulation is acquired by industries, and is designed and operated for their benefit, through the increased market power that regulation allows. By contrast, the Public Interest perspective, as initially suggested by Pigou (1938), holds that industry will be fraught with inefficiencies stemming from market failures of all kinds, if left to its own devices. Regulation is therefore required to achieve socially efficient outcomes. Both perspectives suggest that entry regulation in particular will have an impact on industrial structure by directly influencing the costs of starting a new enterprise in a given industry, but differ in their views on the relative tradeoff between the correction of externalities and the creation of market power. In order to appropriately assess the extent of this tradeoff requires some empirical sense of the actual distortions that may be caused by regulatory burdens. That is the purpose of this paper.

There exists a nascent empirical literature examining the impact of entry regulation on economic outcomes. Two recent papers take contrasting approaches on this issue. Djankov, La Porta, Lopes-de-Silanes, and Shleifer ${ }^{1}$ (2002) document significant differences across countries in the ease with which firms may open new businesses. They go on to examine a number of country-level outcomes and find that, consistent with the Public Choice view, entry regulation is associated with higher corruption and larger unofficial economies, but not higher quality of public or private goods. Bertrand and Kramarz (2002) look more closely at the effects of entry regulation on employment of the

\footnotetext{
${ }^{1}$ Referred to as DLLS below
} 
retail sector in France, taking advantage of regional and temporal variation in the stringency with which entry regulation was applied. They find that entry regulation decreases retail employment, partly due to the increase in concentration and the ensuing price upturns.

In our paper, we take an approach that empirically straddles the two papers described above. We will take advantage of heterogeneity across industries in their natural barriers and growth opportunities to examine whether some industries are differentially affected in countries with high levels of entry regulation. This will allow us to examine how entry regulation differentially influences industrial structure, as a function of industry characteristics, and the opportunities available to firms in that industry. This approach contrasts with DLLS, who examine the impact of regulation only at the country level - our approach will allow for the inclusion of both country and industry fixed-effects, which mitigates some concerns of unobserved heterogeneity and reverse causality. Furthermore, DLLS examine only ultimate (social) outcomes of entry regulation, rather than the direct impact upon industry structure that would be the primary consequence of regulations according to the Public Choice view (in its "acquired regulation" formulation). Also, in contrast to Bertrand and Kramarz, by considering a range of industries and countries, we are able to study the differential impact of regulation across industries, and reflect on how it varies across a much broader range of institutional structures.

Our methodology is similar to the approach popularized by Rajan and Zingales (1998), in that we utilize U.S. data at the industry level to proxy for underlying industry characteristics that have arisen in an economy with relatively few institutional 
constraints. Also following the approach of Rajan and Zingales, we then examine how the relation between (underlying) industry characteristics and actual industry structure is affected by the extent of entry regulation. We report three primary sets of findings; the intuition behind each is summarized in the following paragraph.

First, we consider the effect of entry regulation on the (static) structure of industry. We find that in industries with high natural barriers to entry (and hence little need for additional barriers through regulation), entry regulation has little impact on the quantity and average size of firms in an industry. By contrast, in industries with low natural entry barriers, countries with high entry regulation have few, large firms, relative to less regulated economies. Surprisingly, there is no relation between natural entry barriers and overall industry share of manufacturing, as a function of entry regulation. Second, utilizing firm-level data, we show that operating margins are relatively high in low barrier industries in high entry regulation countries (relative to high natural barrier industries). Together, these results suggest that, while entry regulation does not distort intersectoral allocation, the within-industry organization of production is affected by the regulation of entry. We then examine the impact of entry regulation on industry dynamics, by analyzing the ability of industries to take advantage of shocks to growth opportunities. These results parallel those on static industry structure: in countries with high entry regulation, industries respond to growth opportunities through the expansion of existing firms, while in countries with low entry regulation, the response is primarily through the creation of new firms. Moreover, we find that the investment response to growth opportunities is stronger in countries with low entry regulation, when we limit the 
sample to richer countries. Once again, we find that the total sectoral response is invariant to the level of regulation.

Overall, our results provide a consistent body of evidence suggesting that regulation distorts the (within) structure of industry, promoting industry concentration, but does not have measurable effects on intersectoral allocations. It is plausible that there may be some socially beneficial elements to the entry regulations that we examine. However, given the distortions that we uncover, combined with the absence of any measurable benefits, we argue in our discussion that the results collectively favor the Public Choice view of regulation.

The rest of the paper will be structured as follows: In Section 1, we further elaborate on our methodology. Section 2 describes the datasets that we have brought together for this paper. Our main results and their interpretation are presented in Section 3, and Section 4 contains our conclusions and discussion.

\section{Methodology}

\section{A. Entry Regulation and Industry Structure}

Our first approach is based on the assumption that there exist industries that have 'naturally' high entry barriers. The underlying sources of these barriers are of secondary importance to our study, but may include a range of factors, such as capital intensiveness of production or technological complexity. For our purposes, what is necessary is that there exists some component of these barriers that is industry specific and invariant 
across countries, say $K_{i}$, where $i$ indexes industry. ${ }^{2}$ Furthermore, we observe that models of entry with fixed costs generally predict a convex relationship between the size of fixed costs and the number of firms in an industry. ${ }^{3}$ Thus, we may consider the total (fixed) cost of entry to be $K_{i}+R_{c}$, where $R_{c}$ is the cost associated with entry regulation in country c. Since the number of firms, $N_{i c}$ is convex in $K_{i}+R_{c}, \partial^{2} N_{i c} / \partial K_{i} \partial R_{c}>0$. For constant demand, it also follows that for average firm size, $Q_{i c} / N_{i c}$, $\partial^{2}(Q / N)_{i c} / \partial K_{i} \partial R_{c}<0$, where $Q_{i c}$ is total industry output. The intuition is straightforward: If 'natural' industry entry barriers $K_{i}$ are extremely high (as in, say, petroleum refineries or tobacco), then the marginal impact of an increase in a (relatively small) cost of entry, $R_{c}$, will be small. However, if industry entry barriers are close to zero, the marginal impact of $R_{c}$ may be quite significant.

A suitable test for this conjecture would examine the interaction between natural entry barriers and entry regulation. If the presence of natural entry barriers mitigates the impact of entry regulation on industry structure, we would expect to see this effect empirically in the interaction of (natural) entry barriers and entry regulation. Our regressions will thus take the form:

$$
\begin{aligned}
& \log (\text { No. of firms })_{i c}=\alpha_{i}+\alpha_{c}+\beta^{*}(\text { Entry Barrier })_{i} *(\text { Entry Regulation })_{c}+\varepsilon_{i c} \\
& \text { Log }(\text { Avg. Firm Size })_{i c}=\alpha_{i}+\alpha_{c}+\beta^{*}(\text { Entry Barrier })_{i} *(\text { Entry Regulation })_{c}+\varepsilon_{i c}
\end{aligned}
$$

\footnotetext{
${ }^{2}$ Dunne and Roberts (1991) describe a set of industry characteristics that explain much of inter-industry variations in turnover rates. Furthermore, they find that the correlation between those industry characteristics and the industry turnover pattern is stable over time, which they take as an indication these correlation actually result from differences in technologies across industries. This is confirmed by the evidence presented by Cable and Schwalbach (1991) on systematic inter-industry figures.

${ }^{3}$ This is true, for example, of a simple Cournot model with free entry, and (fixed) linear demand.
} 
For our main results, we will use firm turnover (defined below as entry + exit) in the United States, USTurnover, ${ }_{i}$ as a proxy for industry-specific entry barriers. ${ }^{4}$ High turnover will be taken as a sign of relative ease of entry, i.e., turnover is negatively correlated with entry barriers. ${ }^{5}$ This has been suggested by Dunne and Roberts (1991). They report high inter-industry correlations between entry and exit figures, justifying the characterization of industries with high natural entry barriers as those exhibiting relatively high entry and exit barriers. More specifically, they argue that industries can be characterized by turnover ratios as a function of industry-specific levels of sunk costs. ${ }^{6}$ That suggests translating (1) and (2) into the following specifications that may be estimated with available data:

$$
\begin{aligned}
& \log (\text { No. of firms })_{i c}=\alpha_{i}+\alpha_{c}+\beta * \text { USTurnover }_{i} *\left({\text { Entry Regulation })_{c}+\varepsilon_{i c}}^{\text {Log }(\text { Avg. Firm Size })_{i c}=\alpha_{i}+\alpha_{c}+\beta^{*} \text { USTurnover }} *(\text { Entry Regulation })_{c}+\varepsilon_{i c}\right.
\end{aligned}
$$

As suggested above, we predict a negative coefficient on the interaction term in (3) and a positive coefficient on the interaction term in (4). ${ }^{7}$

\footnotetext{
${ }^{4}$ As a robustness check, we also used the mean industry-level turnover from a set of seven developed countries (Belgium, Canada, Germany, U.K., Norway, Portugal and the USA). Our results are robust to this alternative specification.

${ }^{5}$ One may think of three 'classes' of entry barriers: (1) regulatory (2) 'technical' exogenous (e.g., capital intensity) (3) endogenous but consistent across countries (e.g., advertising). Anything else will be effectively in our error term. Now, our measure of turnover in the U.S. incorporates both (2) and (3), and we cannot differentiate between a technological need for scale, versus an industry's affinity for creating entry barriers through investment. Analyzing these differences would be interesting, since responses may vary according to different types of barriers; we leave this exercise, however, for future research. From our perspective, it does not matter why there exist barriers, simply that they exist and that some component of them is consistent across countries.

${ }^{6}$ An alternative measure of natural entry barriers could be given by considering just the 'entry' rate; however, this measure is more directly influenced by the life cycle of each industry. We include analyses using this alternative measure of entry barriers in the Appendix.

${ }^{7}$ Note that we also ran specifications that looked at the share of number of firms by industry, and found results that paralleled those derived from (3). These results are available from the authors.
} 


\section{B. Entry Regulation and Industry Margins}

It is possible that any effects uncovered by regressions (3) and (4) could be the result of 'artificial' firm boundaries. Under this hypothesis, industry structure is identical across all levels of entry regulation in actual functioning, but there are different demarcations 'on paper' simply to avoid regulatory costs. To test whether there is an impact on actual industry structure, we utilize a measure of operating margins, a dependent variable that directly reflects the ability of firms to set prices above costs. We supplement (3) and (4) with a parallel set of regressions on margins, focusing once again on the interaction of 'natural' entry barriers and regulation:

$$
\text { Margin }_{i c}=\alpha_{i}+\alpha_{c}+\beta^{*} \text { USTurnover }_{i}^{*}(\text { Entry Regulation })_{c}+\varepsilon_{i c}
$$

Since high entry regulation is expected to have a greater impact on market power whenever natural barriers are low (i.e., turnover is high), we expect a positive coefficient in the interaction term in equation (5).

\section{C. Entry Regulation and Response to Growth Opportunities}

We now consider the dynamic effects of entry regulation. If a growth opportunity arises, entry regulation may prevent potential entrants from responding to the new opportunity. ${ }^{8}$ For incumbents, however, the opportunity presents a chance for expansion, protected from the competitive pressures that would be present in less regulated environments.

\footnotetext{
${ }^{8}$ If there exists an optimal firm size, from a technological perspective, all adjustment to demand shocks should take place through changes in the number of firms. The possibility of supply shocks that affect optimal firm structure precludes any general statement on this point.
} 
That is, high entry regulation will promote the expansion of firm size in response to growth opportunities, whereas low entry regulation will promote an expansion in the number of firms where growth opportunities arise. We examine the existence of this differential response by looking at the interaction terms in the following specifications:

$$
\begin{aligned}
& \text { Growth(No. of Firms })_{i c}=\alpha_{i}+\alpha_{c}+ \\
& \quad \beta *(\text { Growth Opportunity })_{i} *(\text { Entry Regulation })_{c}+\varepsilon_{i c}
\end{aligned}
$$

$$
\begin{aligned}
& \text { Growth(Avg. Firm Size })_{i c}=\alpha_{i}+\alpha_{c}+ \\
& \qquad \beta *(\text { Growth Opportunity })_{i} *(\text { Entry Regulation })_{c}+\varepsilon_{i c}
\end{aligned}
$$

Similar to the previous sections, if entry regulation distorts responses to growth opportunities, we predict $\beta<0$ in (6) and $\beta>0$ in (7). Estimating (6) and (7) requires a measure of global shocks to growth opportunities. Following Fisman and Love (2003a), we use actual growth in the United States as a proxy. The rationale is very similar to that described above: assuming that U.S. firms are in an institutional environment that allows them to optimally respond to growth opportunities, we may write:

$$
\text { USGrowth }_{i}=(\text { Global Growth Opportunity })_{i}+\varepsilon_{i U S}
$$

That is, actual growth in the United States is a measure of global shocks to opportunities, plus some U.S.-specific shock $\varepsilon_{i U S}$. We may then simply rewrite (6) and (7) as: 


$$
\operatorname{Growth}(\text { No. of Firms })_{i c}=\alpha_{i}+\alpha_{c}+
$$

$$
\beta *(\text { USGrowth })_{i} *(\text { Entry Regulation })_{c}+\varepsilon_{i c}
$$

$$
\text { Growth(Avg. Firm Size })_{i c}=\alpha_{i}+\alpha_{c}+
$$

$$
\beta *(\text { USGrowth })_{i} *(\text { Entry Regulation })_{c}+\varepsilon_{i c}
$$

\section{Data}

The data on regulation of entry of start-up firms are from DLLS (2002), which contains information on the regulations of 77 countries in 1999. Our choice for the measure of entry regulation includes the entire cost incurred by a prospective firm in order to obtain legal status to operate, as a fraction of per capita GDP. As described by DLLS, it includes all identifiable official expenses, together with the monetary value of the entrepreneur's time. ${ }^{9}$ We acknowledge that, although we limit ourselves to manufacturing industries, there is still very likely within-industry variation in regulation. Unfortunately, we have not been able to obtain reliable information at the industry level; hence, we use the country-level measure of entry regulation described above, keeping this caveat in mind.

As our measure of natural entry barriers, we use firm turnover, as explained in the previous section. Following the intuition of RZ of interpreting US data as industry representative' of an optimal economy, we use US turnover data as our proxy for natural barriers of entry. ${ }^{10}$ We obtain these data from Dunne, Roberts, and Samuelson (1988), which contains firm-level entry and exit data based on U.S. census data; we define

\footnotetext{
${ }^{9}$ This variable is identified as Cost + time in DLLS.

${ }^{10}$ Alternatively, we used average turnover ratios from a subset of 7 countries: Belgium, Canada, Germany, Norway, Portugal, UK and USA (as reported by Roberts, 1996). Our results are robust to this specification.
} 
turnover as the simple sum of entry and exit, deflated by the number of firms in the industry. ${ }^{11}$

High-income countries may be expected to have technological characteristics that are more similar to those of U.S. firms. Hence, U.S. turnover may be a better proxy for technological barriers to entry primarily for richer countries, and as a result, we may wish to restrict our analyses to wealthier countries in what follows. We construct an auxiliary dummy variable called RICH which takes on a value of 1 if the country has per capita income greater than the median of our sample and zero otherwise. Throughout, we will present results for both our full sample of countries, as well as the limited sample of countries with $\mathrm{RICH}=1 .^{12}$ The reasons for this are twofold: first, our U.S.-based proxies for growth opportunities and natural barriers are more applicable to more advanced economies. Also, since the UNIDO data are based on national industrial censuses, data from countries with $\mathrm{RICH}=1$ are of higher quality than that of the less developed countries in the broader sample. ${ }^{13}$

Our outcome variables are derived from the United Nations' UNIDO database, which provides data on production, value-added, number of employees, number of establishments and total wages bill, by industry, for a sample of 57 countries. We will use two country-industry specific outcome variables in our main regressions: average firm size, defined as the (log of the) ratio of industry value added to industry total number of establishments; and the (log of the) number of establishments in each industry. ${ }^{14}$ The use

\footnotetext{
${ }^{11}$ Dunne and Roberts (1986) provides a full description on the data construction.

${ }^{12}$ Countries that have been classified as RICH can be identified in Table 2.

${ }^{13}$ We also computed results using only OECD countries, which generated results very similar to those with $\mathrm{RICH}=1$. When the sample is limited to OECD firms with $\mathrm{RICH}=1$, the results are even stronger than those reported in the text.

${ }^{14}$ These data are available for 52 out of the 57 countries. When merging this data with the regulation data from 77 countries, only 36 countries survive.
} 
of logs allows for a relatively straightforward interpretation of coefficients as elasticities, and also attenuates the effect of any outliers. Following Rajan and Zingales $(1998)^{15}$, we also include an industry's share of total manufacturing production as a control, defined as industry value added generated to total manufacture value added. ${ }^{16}$ Also to be consistent with earlier work, we use the industry composition utilized by RZ, which is a combination of 3- and 4-digit ISIC industries. All of the variables described in this paragraph are constructed using data from 1990.

The UNIDO data do not contain information on industry margins; to fill this gap, we utilize the World Scope Database (WSD), which provides firm-level data on public companies worldwide, representing over $96 \%$ of the world's market value. We define margins as the ratio of operating income to total sales, and generate a measure of margins at the firm level by taking averages over all available years during 1991-97. This is further collapsed to industry-country medians for some of the analyses that follow.

Finally, for our analyses on industry-level responses to growth opportunities as a function of entry regulation, we require a measure of industry-specific growth opportunities. Once again, we follow the intuition of RZ, using industry-level US sales growth as a measure of growth opportunities worldwide. As with turnover, we may be concerned that industry-specific shocks to growth opportunities will be more similar in countries at similar levels of economic development (see Fisman and Love, 2003b, for a discussion); hence, we will once again consider our results for both, the entire sample, as well as the sub sample of countries with $\mathrm{RICH}=1$. The dependent variables in this section are also similar to those used by RZ, and are simply the compounded industry-

\footnotetext{
${ }^{15} \mathrm{RZ}$ hereafter.

16 This variable varies with industry and country, and is therefore not absorbed by the inclusion of country and industry dummies.
} 
level growth rates of average firm size and number of firms, as well as growth in value added, as defined above, during 1981-90. ${ }^{17}$

There may be some concerns that regulation is endogenous to industrial structure (entry regulation being a result of high industry concentration). Even though this is not likely to apply to our focus of analysis on the differential impact of regulation across different types of industries (see next section for more details), we address these concerns by undertaking an instrumental variables approach. In particular, we use legal origin, from La Porta et al (1998); as well, we utilize dummy variables reflecting majoritarian (versus proportional) and presidential (versus parliamentary) political systems. ${ }^{18}$

Finally, we will consider the effect of other regulation on industry structure. According to the Public Choice theory of government intervention, any regulation may indeed serve as an entry barrier, and may therefore potentially have a distortionary effect on industry structure. We use an index of labor regulation as our primary alternative measure of regulation, derived from Botero et al (2003), which measures the level of protection of labor and employment laws, taking into account availability of alternative employment contracts, conditions of employments and job security. As a coarser, alternative summary measure of regulation, we use an index derived from Holmes, Johnson, and Kirkpatrick (1997).

Table 1 provides details on the construction and source for each of our variables, and Table 2 lists summary statistics, by country and by industry. Panel A reports countrylevel statistics; Panel B presents industry-level summary statistics of our main variables.

\footnotetext{
${ }^{17}$ The reason for dropping the year 1980 is the amount of missing observation in some of our key variables.

${ }^{18}$ We thank Torsten Persson for providing us with these data.
} 


\section{Results}

Before proceeding to regressions, we present some basic cross-tabulations to illustrate the patterns in the raw data. In these cross-tabs, we limit observations to countries with $R I C H=1$, to control in a limited way for income effects. In Table 3, we start by showing the data classified in high versus low turnover industries (where turnover is a proxy for natural entry barriers), and high versus low entry regulation countries. Table 3(a) shows the total share in the number of firms for high versus low turnover industries. A much larger number of firms are in high turnover industries, which is implied by the summary statistics listed in Table 2. Consistent with our conjecture on the impact of entry regulation, the differential between high and low turnover firms is much smaller for countries with high entry regulation. Table 3 (b) shows a similar set of results for average firm size, where we find that the gap between the size of firms in low versus high turnover industries is narrower for countries with high entry regulation. Surprisingly, average firm size is larger overall in low entry regulation countries; in our regressions, however, all country-specific factors will be absorbed by fixed-effects, which will allow for a cleaner comparison on the differential effects of entry regulation by industry. These results are illustrated in the two upper plots of Figure 1. Additionally, Table 3(c) shows that margins are indeed higher in low turnover industries, and that the gap is narrower in high regulation countries. This simple cross-tabulation shows that average margins are lower in high regulation countries, but this will once again be absorbed by country-level fixed effects.

Table 3 (d) and (e) show cross tabulations that illustrate the effects of entry regulation on firms' responses to growth opportunities, by splitting the sample into high 
and low growth opportunity industries (as measured by actual growth in the U.S.). In Table 3 (d), we look at growth in the number of establishments; we observe that in general, the number of establishments grows more within industries with relatively higher growth opportunities. However, this differential is much greater in countries where entry regulation is low. Finally, Table 3 (e) shows the growth rate in average establishment size, where we observe that industries located in countries with high entry regulation exhibit relatively higher growth rates in average establishment size in industries with higher growth opportunities. We plot these results in the lower section of Figure 1.

\section{A. Entry Regulation and Industry Structure: Regression Results}

Our estimations of equation (3) and (4) are listed in Table 4. In columns (1) and (2) of Panel A, we show our baseline results, for the full sample and without any additional controls. The coefficients of interest are of the predicted signs, and are significant at least at the 5 percent level. Furthermore, the magnitudes are large, and may be illustrated with the following thought experiment: In moving from Singapore, the country at the $25^{\text {th }}$ percentile of the distribution of entry barriers, to Peru, the country at the $75^{\text {th }}$ percentile, the difference between the number of firms in Paper and Allied Products $\left(25^{\text {th }}\right.$ percentile of USTurnover) and the number of firms in Industrial Machinery and Equipment $\left(75^{\text {th }}\right.$ percentile of USTurnover) narrows by 11.03 percent $((0.81-0.61) *(-0.28+0.68)) *(-$ 1.379). Similarly, the difference in average firm size narrows by 4.76 percent $((0.82-$ $0.61) *(-0.28+0.68))^{*}(0.595) .^{19}$

\footnotetext{
${ }^{19}$ I.e., the slope relating number of firms to USTurnover is less positive in Peru than in Singapore, and the slope relating average firm size to USTurnover is less negative in Peru than in Singapore.
} 
We add $\log (G D P) *$ USTurnover as a control in columns (3) and (4), and find that the size of our coefficients are reduced (in absolute values) but their significance increases to the $1 \%$ level. Finally, in columns (5) through (8), we restrict the sample to countries with $\mathrm{RICH}=1$, and find that for this subsample the coefficients show a stronger and more significant effect on average firm size. ${ }^{20}$

In Panel B, we repeat the same set of regressions, but with Sector Share ${ }_{i c}$ as the outcome variable. Interestingly, this does not generate any significant coefficients once we control for the interaction of turnover with the GDP per capita. Our standard errors in these regressions are not increased, relative to the preceding set of regressions, suggesting that the effect of regulation does not distort total intersectoral allocations. Rather, the regulations affect industry structure through within-industry distortions.

\section{B. Entry Regulation and Operating Margins: Regression Results}

We present our estimation of equation (5) in Table 5. The coefficient on the interaction term is positive, suggesting that entry regulation disproportionately generates market power for firms in high-turnover industries. It is highly significant in all regressions once we either control for the interaction of GDP per capita and turnover or when the sample is limited to the subset of "rich" countries. A similar thought experiment to that described above suggests that in moving from Singapore to Peru, the gap in margins between 'high' and 'low' regulation industries increases by approximately 0.4 percentage points.

\section{C. Entry Regulation and Responses to Growth Opportunities: Regression Results}

\footnotetext{
${ }^{20}$ In order to address a potential concern on the endogeneity of our control variable 'sector share', we also estimate these regressions without including such controls. The coefficients of interest remain significant at conventional levels in models (2) through (8).
} 
To analyze the dynamic effects of entry regulation, we turn to the empirical tests described in (9) and (10), and reported in Table 6. The full-sample regressions yield significant coefficients in the regressions examining growth in the number of establishments: there is a smaller response to growth opportunities in those countries with higher barriers to entry. The coefficients in the regressions examining average establishment size are of the predicted sign, but not significant at conventional levels. However, when we limit the sample to countries with $\mathrm{RICH}=1$, both sets of coefficients are significant and of the predicted sign (see columns (5) and (6)).

\section{D. Robustness Checks}

\section{Instrumenting for Regulation}

There may be some concern that regulation is endogenous to industrial structure. Thus, for example, countries with high industry concentration may have high entry regulation, because of lobbying. Under a more benign interpretation, countries that differentially benefit from industrial concentration may choose high levels of regulation. We begin by noting that this does not necessarily contaminate our results: we are interested exclusively in the differential impact of regulation across different types of industries, so that these interpretations would similarly have to imply differential effects across industries to account for our results. To try to address these concerns, we consider several variables that describe a country's legal and political structure as instruments. In particular, we use legal origin, as popularized by La Porta et al (1998), as well as dummies that indicate whether a country has a presidential (versus parliamentary) political system and whether a country has a majoritarian (versus proportional representation) voting structure. 
Persson and Tabellini (2003) and others have argued that these variables significantly impact both the size of government, as well as the extent to which governments intervene in the economy.

To be effective instruments, these variables must collectively be predictive of the extent of entry regulation, i.e., the instruments are significant in the first stage, and the instruments must only (differentially) affect our outcome variables through their impact

on entry regulation. While we cannot rule out the effect of government structure on industry organization outside of regulation, this is the most natural channel through which government may influence industry structure. Now, since we are using these variables as instruments for regulation interacted with either turnover or USgrowth, the instruments themselves will be interaction terms. In the first stage, our collection of instruments is significant at the 1 percent level (based on an F-test); our presidential dummy interaction is not significant, but all others are individually significant. In the second stages, reported for the sub sample of rich countries in Table 7, we find that the magnitudes of the coefficients generated by the instrumental variables approach are very similar to those in our OLS regressions. Furthermore, with the exception of the results on margins, all coefficients remain significant at conventional levels.

\section{E. Other Forms of Regulation}

In this paper, we have focused on the specific type of regulation that we expect to most directly impact industry structure, due to the effect on the fixed cost of entry, relative to production (fixed or marginal) costs. However, our explanation could potentially apply to other types of indirect regulatory barriers to entry, which are correlated with entry 
regulation. We therefore wish to get a sense of whether regulation generally is distorting industrial structure by acting as a barrier to entry, or whether there is something special about regulation of entry. We therefore provide an alternative set of results that examine the impact of labor regulations, based on the data collected by Botero et al (2003).

In Table 8 we show the results of all our main regressions. In the interests of space, we report only those regressions considering the sub-sample of rich countries and those where GDP per capita interactions have been included. Given the entry regulation results, it is remarkable that none of the interaction terms involving labor regulation are significant. We have also repeated these regressions using the overall measure of government intervention of Holmes, Johnson, and Kirkpatrick (1997), and find that almost all coefficients are insignificant at the 10 percent level.

\section{F. Additional Robustness Checks}

As Djankov et al (2003) have noted, regulation is correlated with various other countrylevel characteristics. While the most obvious control, $\log$ (GDP per capita), is included in all reported specifications, there may be concerns of other omitted variables. We therefore repeated our full set of regressions including interactions involving a number of additional covariates that might be expected to impact industry structure. First, we consider interactions with a measure of financial market development, taken from Rajan and Zingales, defined as the ratio of private domestic credit and stock market capitalization to GDP. As well, we consider the effect of including interactive controls utilizing the country-level measure of corruption developed by Kaufmann, Kraay, and Zoido-Lobatón (2003). Finally, we try to control for overall bureaucratic quality using a 
measure from Political Risk Services (1997). In no case were any of the coefficients systematically significant. Furthermore, the coefficients on the interaction terms reported above were uniformly unaffected by the inclusion of these additional interaction terms. ${ }^{21}$

A second concern that affects the "average size" specification is that our measure of firm size is based on value added, which incorporates both prices and quantities produced. To ensure that these results are not driven purely by price effects, but signify 'real' distortions, we repeat these specifications using employment-based measures of firm size, also derived from the UNIDO data. These results are reported in Table AP1 of the Appendix, and parallel the firm size results based on firm value-added.

As a final robustness check, we estimate analogous regressions using USEntry instead of USTurnover as a proxy for entry barriers. These results are listed in Table AP2 of the Appendix; the coefficients in all regressions remain significant at conventional levels, and are generally larger in magnitude than those reported in the main text.

\section{Conclusions}

In this paper, we study the distortions to the organization of industry caused by entry regulation, taking advantage of heterogeneity across industries in their natural barriers and growth opportunities to examine whether some industries are differentially affected in countries with high levels of entry regulation. First, we consider the effect of entry regulation on the (static) structure of industry. We find that in industries with high 'natural' barriers to entry, as proxied by firm turnover in the U.S., entry regulation has little impact on the quantity and average size of firms in an industry. By contrast, in

\footnotetext{
${ }^{21}$ These results can be obtained from the authors.
} 
industries with low 'natural' entry barriers, countries with high entry regulation have few, large firms, relative to less regulated economies. We find no relation between 'natural' entry barriers and overall industry share of manufacturing, as a function of entry regulation. Second, utilizing firm-level data, we show that operating margins are relatively high in low barrier industries in high entry regulation countries (relative to high 'natural' barrier industries). Finally, we examine the impact of entry regulation on industry dynamics, by analyzing the ability of industries to take advantage of shocks to growth opportunities, and find that in countries with high entry regulation, industries respond to growth opportunities through the expansion of existing firms, while in countries with low entry regulation, the response is primarily through the creation of new firms; the total sectoral response is invariant to the level of regulation. Overall, our results provide a consistent body of evidence suggesting that regulation distorts the (within) structure of industry, promoting industry concentration, but does not have measurable effects on intersectoral allocations.

It is worth noting, in conclusion, some potential policy implications of our findings. The Public Interest view does allow for the possibility that industrial organization may be distorted through the creation of regulatory entry barriers. However, the particular form of regulations that we examine here, in contrast to the regulation of labor, environmental contaminants, or product safety, do not provide obvious social returns. Therefore, the market power and distortions in industry structure that we report may not be offset by social gains. We leave further analysis on the overall welfare implications of regulation as an area for further research. 


\section{References}

Bertrand M. and Kramarz F., Does Entry Regulation Hinder Job Creation? Evidence from the French Retail Industry, IZA Discussion Paper No. 415, 2002.

Botero, j., Djankov, S., La Porta, R. and Lopez-de-Silanes, F., The Regulation of Labor, Working Paper, revised March, 2003.

Cable, J. and Schwalbach, J., International Comparisons of Entry and Exit. Entry and Market Contestability, An International Comparison. Edited by P.A. Geroski and J. Schwalbach, Blackwell 1991, 257-281.

Djankov, La Porta, Lopes-de-Silanes, and Shleifer, The Regulation of Entry, Quarterly Journal of Economics, Vol CXVII, Issue 1, 2002.

Djankov S., Glaeser, E., La Porta, R., Lopez-de-Silanes, F. and Shleifer, A., The New Comparative Economics, Working Paper, 2003.

Dunne, T., Roberts, M.J. and Samuelson, L., Patterns of Firm Entry and Exit in U.S. Manufacturing Industries. Rand Journal of Economics, Volume 19, Issue 4, 1988, pp. 495-515.

Dunne, T. and Roberts, M.J., Variation in Producer Turnover Across US Manufacturing Industries. Entry and Market Contestability, An International Comparison. Edited by P.A. Geroski and J. Schwalbach, Blackwell 1991, 187-203.

Fisman R. and Love I., Financial Development and the Composition of Industrial Growth, Working Paper, 2003.

Fisman R. and Love I. , Financial Dependence and Growth: A Comment, Working Paper, 2003a.

Holmes, K.R., Johnson, B.T. and Kirkpatrick, M., Index of Economic Freedom. Washington, D.C. and New York, 1997.

Kaufmann, D., Kraay, A. and Zoido-Lobatón, P., Aggregating Governance Indicators, World Bank PolicyResearch Department Working Paper No. 2195, 1999.

La Porta, R., Lopez-de-Silanes, F., Shleifer, A. and Vishny, R.W., Law and Finance, Journal of Political Economy, 106, 1113-55.

Pigou, A. C., The Economics of Welfare, $4^{\text {th }}$ ed. (London: Macmillan and Co.), 1938.

Rajan R. G. and Zingales L., Financial Dependence and Growth. The American Economic Review, Vol 88, Issue 3, 1998, pp559-586. 
Roberts, M. J., Employment Flows and Producer Turnover. Industrial evolution in developing countries : micro patterns of turnover, productivity, and market structure. Edited by Mark J. Roberts and James R. Tybout.

Stigler G. J., The Theory of Economic Regulation, The Bell Journal of Economics and Management Science, Volume 2, Issue 1, 1971, pp.3-21. 
Table 1 - Table 1 introduces variables abbreviations, definitions and sources

\begin{tabular}{|c|c|c|}
\hline Category & Abbreviation & "Description and Sources \\
\hline Dependent & $\begin{array}{l}\text { Log (Number) } \\
\text { Sector Share } \\
\text { Margin } \\
\text { Growth_VA } \\
\text { Growth_No } \\
\text { Growth_Avsz }\end{array}$ & $\begin{array}{l}\text { Log of the ratio of industry value added to industry total } \\
\text { number of establishments in each industry for year } 1990 . \\
\text { The industry composition is a combination of 3- and 4-digit } \\
\text { ISIC industries. From United Nations' UNIDO database. } \\
\text { Log of the number of establishments in each industry for } \\
\text { year 1990. Source: UNIDO. } \\
\text { By country measure of industry's share of total value added } \\
\text { in manufacturing sector in 1990. Source UNIDO. } \\
\text { Firms' average ratio of operating income to total assets } \\
\text { during the period 1991-1997. Source: World Scope } \\
\text { Database. } \\
\text { Compounded industry-level growth rate of value added, } \\
\text { during 1981-1990. Source UNIDO. } \\
\text { Compounded industry-level growth rate of number of } \\
\text { establishments, during 1981-1990. Source UNIDO. } \\
\text { Compounded industry-level growth rate of firms' average } \\
\text { size (as defined in the first line). Period 1981-1990. From } \\
\text { UNIDO. }\end{array}$ \\
\hline $\begin{array}{l}\text { Alternative } \\
\text { Dependent } \\
\text { Variables }\end{array}$ & $\begin{array}{l}\text { Log (Avemp) } \\
\text { Gwth_Avemp }\end{array}$ & $\begin{array}{l}\text { Log of the ratio of industry number of employees to industry } \\
\text { number of establishments, year } 1990 \text {. Source UNIDO. } \\
\text { Compounded industry-level growth rate of the ratio defined } \\
\text { above, during 1981-1990. Source: UNIDO. }\end{array}$ \\
\hline $\begin{array}{l}\text { and } \\
\text { Controls }\end{array}$ & $\begin{array}{l}\text { USGrowth } \\
\text { Log (GDPPC) } \\
\text { Rich } \\
\text { Log Assets }\end{array}$ & $\begin{array}{l}\text { Total costs incurred by a prospective firm in order to obtain } \\
\text { status to operate, as a fraction of per capita GDP. It includes } \\
\text { identifiable official expenses, as well as monetary value of } \\
\text { the entrepreneur's time. Source: Djankov, La Porta, Lopez- } \\
\text { de-Silanes and Shleifer (2002). } \\
\text { Sum of the average entry and exit rates for the US } \\
\text { manufacturing sector over the period 1963-82. From Dunne, } \\
\text { Roberts and Samuelson (1988). } \\
\text { Growth in real sales, industry-level median of firm average } \\
\text { growth rates over the period 1981-1990 for each ISIC } \\
\text { industry in the US. Source: Compustat. } \\
\text { Log of GDP per capita, dollars in 1980. } \\
\text { Dummy variable which equals } 1 \text { if the country has per capita } \\
\text { income greater than the median in the sample and zero } \\
\text { otherwise. } \\
\text { Log value of firms' total assets. } \\
\text { Measures the level of protection provided by labor and } \\
\text { employment laws. It takes into account availability of } \\
\text { alternative employment contracts, conditions of } \\
\text { employments and job security. From Botero et al (2003). }\end{array}$ \\
\hline
\end{tabular}


Table 2 - Table 2 Panel A shows the number of observations by country, and summarizes country-level of entry barrier regulation. Entry_Reg is defined in Table 1. It ranges from 0.173 to 2.714 .

\begin{tabular}{|c|c|c|}
\hline Country & Observations & Entry_Reg \\
\hline Australia (*) & 36 & 0.0305 \\
\hline Austria $(*)$ & 28 & 0.4208 \\
\hline Belgium (*) & 13 & 0.2318 \\
\hline Brazil & 13 & 0.4534 \\
\hline Canada (*) & 35 & 0.0225 \\
\hline Chile & 28 & 0.2428 \\
\hline Colombia & 36 & 0.3400 \\
\hline Denmark $(*)$ & 28 & 0.1120 \\
\hline Egypt, Arab Rep. & 28 & 1.1699 \\
\hline Finland $(*)$ & 36 & 0.1076 \\
\hline France $(*)$ & 28 & 0.3550 \\
\hline Greece $(*)$ & 36 & 0.7300 \\
\hline India & 30 & 0.8856 \\
\hline Indonesia & 36 & 1.0499 \\
\hline Italy $(*)$ & 28 & 0.4482 \\
\hline Jamaica & 9 & 0.2839 \\
\hline Japan $(*)$ & 28 & 0.2201 \\
\hline Jordan & 25 & 0.7929 \\
\hline Kenya & 24 & 0.7230 \\
\hline Korea, Rep. & 36 & 0.2707 \\
\hline Malaysia & 35 & 0.4325 \\
\hline Mexico & 26 & 0.8344 \\
\hline New Zealand (*) & 25 & 0.0173 \\
\hline Norway $(*)$ & 35 & 0.1192 \\
\hline Peru & 28 & 0.5306 \\
\hline Philippines & 28 & 0.3737 \\
\hline Portugal & 34 & 0.4884 \\
\hline Singapore $(*)$ & 27 & 0.2071 \\
\hline Spain $(*)$ & 36 & 0.5010 \\
\hline Sri Lanka & 26 & 0.2892 \\
\hline South Africa (*) & 24 & 0.1884 \\
\hline Sweden $(*)$ & 35 & 0.0776 \\
\hline Turkey & 36 & 0.3692 \\
\hline United Kingdom (*) & 36 & 0.0303 \\
\hline Venezuela $(*)$ & 35 & 0.5220 \\
\hline Zambia & 18 & 0.7209 \\
\hline
\end{tabular}

(*) Included in the RICH countries subsample. 
Table 2 - Table 2 Panel B shows some industry-level summary statistics. It includes the mean level of turnover, and the mean values and growth rates of value added, total number of establishments and average size. It also includes the compounding growth rates for the last three variables.

\begin{tabular}{|c|c|c|c|c|c|}
\hline $\begin{array}{l}\text { ISIC } \\
\text { Code }\end{array}$ & Observations & Turnover & $\begin{array}{l}\text { Value Added } \\
\text { (in Millions) }\end{array}$ & $\begin{array}{c}\text { Number of } \\
\text { Establishments }\end{array}$ & $\begin{array}{l}\text { Average } \\
\text { Size }\end{array}$ \\
\hline 311 & 34 & 0.5520 & 5800.00 & 6175.53 & $1,705,429$ \\
\hline 313 & 32 & 0.5520 & 1393.00 & 522.75 & $6,728,204$ \\
\hline 314 & 32 & 0.4280 & 673.70 & 310.03 & $45,200,000$ \\
\hline 321 & 33 & 0.7440 & 2652.00 & 2933.61 & $1,469,825$ \\
\hline 322 & 32 & 0.8560 & 1226.00 & 2893.19 & 604,451 \\
\hline 323 & 29 & 0.6840 & 227.20 & 419.76 & 617,071 \\
\hline 324 & 30 & 0.6840 & 296.30 & 477.33 & $1,001,990$ \\
\hline 331 & 29 & 0.9380 & 1257.00 & 2696.38 & 834,257 \\
\hline 332 & 33 & 0.9020 & 836.30 & 1851.85 & 627,089 \\
\hline 341 & 33 & 0.6130 & 2138.00 & 737.91 & $4,737,221$ \\
\hline 342 & 33 & 0.9190 & 3357.00 & 2804.27 & $1,447,248$ \\
\hline 351 & 30 & 0.6100 & 2972.00 & 359.40 & $7,146,255$ \\
\hline 352 & 31 & 0.6100 & 3304.00 & 672.61 & $4,333,831$ \\
\hline 353 & 26 & 0.6340 & 1414.00 & 21.88 & $129,000,000$ \\
\hline 354 & 25 & 0.6340 & 224.40 & 107.24 & $3,256,232$ \\
\hline 355 & 33 & 0.7330 & 903.10 & 408.09 & $2,751,022$ \\
\hline 356 & 32 & 0.7330 & 1977.00 & 1474.56 & $1,271,827$ \\
\hline 361 & 28 & 0.6510 & 353.80 & 353.00 & $3,165,247$ \\
\hline 362 & 28 & 0.6510 & 669.70 & 209.21 & $3,931,853$ \\
\hline 369 & 30 & 0.6510 & 2199.00 & 1785.50 & $1,793,126$ \\
\hline 371 & 29 & 0.5960 & 3297.00 & 619.86 & $7,335,015$ \\
\hline 372 & 29 & 0.5960 & 1205.00 & 370.03 & $8,723,221$ \\
\hline 381 & 31 & 0.7840 & 4056.00 & 4704.42 & $1,089,325$ \\
\hline 382 & 32 & 0.8380 & 7475.00 & 4221.09 & $1,841,720$ \\
\hline 383 & 32 & 0.8120 & 7488.00 & 2239.94 & $3,567,359$ \\
\hline 384 & 32 & 0.7920 & 6743.00 & 1277.03 & $4,890,212$ \\
\hline 385 & 30 & 1.0710 & 816.10 & 474.67 & $2,037,780$ \\
\hline 390 & 32 & 0.8120 & 797.60 & 1288.50 & 784,799 \\
\hline
\end{tabular}


Table 2 - Panel B (Cont'd)

\begin{tabular}{|c|c|c|c|c|}
\hline ISIC Code & Observations & $\begin{array}{c}\text { Value Added } \\
\text { Growth }\end{array}$ & $\begin{array}{c}\text { Number Est. } \\
\text { Growth }\end{array}$ & $\begin{array}{c}\text { Average Size } \\
\text { Growth }\end{array}$ \\
\hline 311 & 32 & 0.0792 & 0.03 & 0.05 \\
\hline 313 & 30 & 0.0737 & 0.00 & 0.08 \\
\hline 314 & 29 & 0.0683 & 0.00 & 0.08 \\
\hline 321 & 31 & 0.0433 & 0.01 & 0.04 \\
\hline 322 & 30 & 0.0733 & 0.05 & 0.04 \\
\hline 323 & 28 & 0.0554 & 0.02 & 0.04 \\
\hline 324 & 28 & 0.0350 & 0.01 & 0.03 \\
\hline 331 & 27 & 0.0482 & 0.03 & 0.02 \\
\hline 332 & 30 & 0.0644 & 0.05 & 0.03 \\
\hline 341 & 31 & 0.0803 & 0.02 & 0.07 \\
\hline 342 & 30 & 0.0726 & 0.04 & 0.04 \\
\hline 351 & 29 & 0.0959 & 0.03 & 0.07 \\
\hline 352 & 30 & 0.0783 & 0.01 & 0.08 \\
\hline 353 & 25 & 0.0823 & 0.01 & 0.08 \\
\hline 354 & 23 & 0.0719 & 0.02 & 0.05 \\
\hline 355 & 31 & 0.0416 & 0.03 & 0.02 \\
\hline 356 & 29 & 0.0971 & 0.04 & 0.06 \\
\hline 361 & 26 & 0.0704 & 0.06 & 0.02 \\
\hline 362 & 27 & 0.0622 & 0.02 & 0.05 \\
\hline 369 & 29 & 0.0596 & 0.02 & 0.05 \\
\hline 371 & 27 & 0.0545 & 0.00 & 0.06 \\
\hline 372 & 27 & 0.0846 & 0.02 & 0.07 \\
\hline 381 & 30 & 0.0614 & 0.04 & 0.03 \\
\hline 382 & 30 & 0.0704 & 0.05 & 0.03 \\
\hline 383 & 30 & 0.0740 & 0.04 & 0.03 \\
\hline 384 & 30 & 0.0547 & 0.03 & 0.03 \\
\hline 385 & 27 & 0.0916 & 0.03 & 0.07 \\
\hline 390 & 30 & 0.0785 & 0.04 & 0.06 \\
\hline
\end{tabular}


TABLE 3

PANEL A: Shows the Average Number of Establishments

\begin{tabular}{c|cc}
\hline \hline $\begin{array}{c}\text { Average } \\
\text { Number of Establishments }\end{array}$ & Low Entry Reg & High Entry Reg \\
\hline \hline Low Turnover & 0.2052 & 0.2952 \\
\hline High Turnover & 0.7066 & 0.6151 \\
\hline \hline
\end{tabular}

PANEL B: Shows Firm Average Size (measured as the ratio of Industry Value Added to Industry Number of Establishments)

\begin{tabular}{c|cc}
\hline \hline $\begin{array}{c}\text { Average } \\
\text { Size (in Millions) }\end{array}$ & Low Entry Reg & High Entry Reg \\
\hline \hline Low Turnover & 17,9409 & 13.6990 \\
\hline High Turnover & 2.1633 & 2.2822 \\
\hline \hline
\end{tabular}

PANEL C: Shows the Average Margin

\begin{tabular}{c|cc}
\hline $\begin{array}{c}\text { Average } \\
\text { Margin }\end{array}$ & Low Entry Reg & High Entry Reg \\
\hline \hline Low Turnover & 0.0839 & 0.0587 \\
\hline High Turnover & 0.0755 & 0.0570 \\
\hline \hline
\end{tabular}


TABLE 3 CONT'D

PANEL D: Shows the Growth rate of the Average Number of Establishments

\begin{tabular}{c|cc}
\hline \hline $\begin{array}{c}\text { Average } \\
\text { Number of Establishments }\end{array}$ & Low Entry Reg & High Entry Reg \\
\hline \hline Low Growth Opportunities & 0.0037 & 0.0004 \\
\hline High Growth Opportunities & 0.0255 & 0.0035 \\
\hline \hline
\end{tabular}

PANEL E: Shows the Growth rate of the Firm Average Size

\begin{tabular}{c|cc}
\hline \hline $\begin{array}{c}\text { Average } \\
\text { Size }\end{array}$ & Low Entry Reg & High Entry Reg \\
\hline \hline Low Growth Opportunities & 0.0526 & 0.0509 \\
\hline High Growth Opportunities & 0.0517 & 0.0504 \\
\hline \hline
\end{tabular}


TABLE 4 - Table 4 shows the regression analysis of the relationship between Entry Regulation and Industry Structure. Avsz represents the Firm Average Size measured as the ratio of Industry Value Added to Industry Number of Establishments and Number measures the Industry Number of Establishments. All regressions include country and industry dummies. $* * *, * *$ and $*$ represent coefficients significant at the $1 \%, 5 \%$, and $10 \%$ levels respectively. Standard errors in brackets.

PANEL A: Within-industry Effect

\begin{tabular}{|c|c|c|c|c|c|c|c|c|}
\hline Model & (1) & (2) & (3) & (4) & $(5)$ & (6) & (7) & $(8)$ \\
\hline Sample & \multicolumn{4}{|c|}{ All Countries } & \multicolumn{4}{|c|}{ Rich Countries } \\
\hline Dep. Variable & Log(Avsz) & Log(Number) & Log(Avsz) & Log(Number) & Log(Avsz) & Log(Number) & Log(Avsz) & Log(Number) \\
\hline $\begin{array}{l}\text { Turnover * } \\
\text { Entry_Reg }\end{array}$ & $\begin{array}{c}0.595 * * \\
{[0.237]}\end{array}$ & $\begin{array}{c}-1.379 * * * \\
{[0.251]}\end{array}$ & $\begin{array}{c}0.555 * * * \\
{[0.177]}\end{array}$ & $\begin{array}{c}-1.000 * * * \\
{[0.180]}\end{array}$ & $\begin{array}{c}0.626 * * * \\
{[0.204]}\end{array}$ & $\begin{array}{c}-1.087 * * * \\
{[0.215]}\end{array}$ & $\begin{array}{c}0.631 * * * \\
{[0.179]}\end{array}$ & $\begin{array}{c}-0.902 * * * \\
{[0.233]}\end{array}$ \\
\hline $\begin{array}{l}\text { Turnover * } \\
\qquad \log (\text { GDPPC })\end{array}$ & & & $\begin{array}{c}-0.057 \\
{[0.319]}\end{array}$ & $\begin{array}{c}0.535 \\
{[0.398]}\end{array}$ & & & $\begin{array}{c}0.027 \\
{[0.570]}\end{array}$ & $\begin{array}{c}0.945 \\
{[0.744]}\end{array}$ \\
\hline Sector Share & $\begin{array}{c}8.719 * * * \\
{[1.491]}\end{array}$ & $\begin{array}{c}8.733 * * * \\
{[1.860]}\end{array}$ & $\begin{array}{c}8.763 * * * \\
{[1.485]}\end{array}$ & $\begin{array}{c}8.318 * * * \\
{[1.745]}\end{array}$ & $\begin{array}{c}9.356 * * * \\
{[1.502]}\end{array}$ & $\begin{array}{c}6.488 * * * \\
{[1.975]}\end{array}$ & $\begin{array}{c}9.351 * * * \\
{[1.521]}\end{array}$ & $\begin{array}{c}6.310 * * * \\
{[1.930]}\end{array}$ \\
\hline Constant & $\begin{array}{c}18.248 * * * \\
{[0.699]}\end{array}$ & $\begin{array}{c}-2.218 * * * \\
{[0.738]}\end{array}$ & $\begin{array}{c}17.108 * * * \\
{[1.247]}\end{array}$ & $\begin{array}{l}-1.956 \\
{[1.518]}\end{array}$ & $\begin{array}{c}13.026 * * * \\
{[0.136]}\end{array}$ & $\begin{array}{c}5.668 * * * \\
{[0.171]}\end{array}$ & $\begin{array}{c}13.903 * * \\
{[5.151]}\end{array}$ & $\begin{array}{l}-4.816 \\
{[6.672]}\end{array}$ \\
\hline $\begin{array}{l}\text { Observations } \\
\text { R-squared }\end{array}$ & $\begin{array}{l}860 \\
0.86\end{array}$ & $\begin{array}{c}860 \\
0.89\end{array}$ & $\begin{array}{c}860 \\
0.86\end{array}$ & $\begin{array}{r}860 \\
0.89\end{array}$ & $\begin{array}{l}419 \\
0.89\end{array}$ & $\begin{array}{l}419 \\
0.92\end{array}$ & $\begin{array}{l}419 \\
0.89\end{array}$ & $\begin{array}{l}419 \\
0.93\end{array}$ \\
\hline
\end{tabular}


TABLE 4 - CONT'D

PANEL B: Inter-industry Effect

\begin{tabular}{|c|c|c|c|c|}
\hline Model & (1) & (2) & (3) & (4) \\
\hline Sample & \multicolumn{2}{|c|}{ All Countries } & \multicolumn{2}{|c|}{ Rich Countries } \\
\hline Dep. Variable & Sector Share & Sector Share & Sector Share & Sector Share \\
\hline $\begin{array}{l}\text { Turnover * } \\
\text { Entry_Reg }\end{array}$ & $\begin{array}{c}-0.027 * * * \\
{[0.008]}\end{array}$ & $\begin{array}{c}0.001 \\
{[0.011]}\end{array}$ & $\begin{array}{c}-0.008 \\
{[0.009]}\end{array}$ & $\begin{array}{c}0.000 \\
{[0.009]}\end{array}$ \\
\hline $\begin{array}{l}\text { Turnover* } \\
\qquad \log (\text { GDPPC })\end{array}$ & & $\begin{array}{c}0.037 * * \\
{[0.015]}\end{array}$ & & $\begin{array}{c}0.043 * * \\
{[0.018]}\end{array}$ \\
\hline Constant & $\begin{array}{c}-0.069 * * \\
{[0.025]}\end{array}$ & $\begin{array}{c}-0.323 * * * \\
{[0.110]}\end{array}$ & $\begin{array}{c}-0.014 \\
{[0.029]}\end{array}$ & $\begin{array}{c}-0.149 * * \\
{[0.069]}\end{array}$ \\
\hline $\begin{array}{l}\text { Observations } \\
\text { R-squared }\end{array}$ & $\begin{array}{c}958 \\
0.48\end{array}$ & $\begin{array}{l}958 \\
0.5\end{array}$ & $\begin{array}{l}478 \\
0.53\end{array}$ & $\begin{array}{l}478 \\
0.54\end{array}$ \\
\hline
\end{tabular}


TABLE 5 - Table 5 shows the regression analysis of the relationship between Entry Regulation and Industry Margin. Margin is defined as the ratio of Operating Income over Sales. All regressions include country and industry dummies. ***, ** and * represent coefficients significant at the $1 \%, 5 \%$, and $10 \%$ levels respectively. Standard errors in brackets.

\begin{tabular}{|c|c|c|c|c|}
\hline Model & -1 & -2 & -3 & -4 \\
\hline Sample & \multicolumn{2}{|c|}{ All Countries } & \multicolumn{2}{|c|}{ Rich Countries } \\
\hline Dep. Variable & Margin & Margin & Margin & Margin \\
\hline $\begin{array}{l}\text { Turnover } * \\
\text { Entry_Reg }\end{array}$ & $\begin{array}{c}0,012 \\
{[0.014]}\end{array}$ & $\begin{array}{c}0.032 * * \\
{[0.012]}\end{array}$ & $\begin{array}{c}0.038 * * \\
{[0.013]}\end{array}$ & $\begin{array}{c}0.039 * * * \\
{[0.013]}\end{array}$ \\
\hline $\begin{array}{l}\text { Turnover * } \\
\qquad \log (\text { GDPPC })\end{array}$ & & $\begin{array}{l}0.028 * \\
{[0.015]}\end{array}$ & & $\begin{array}{c}0,007 \\
{[0.026]}\end{array}$ \\
\hline Log Assets & $\begin{array}{c}0.007 * * \\
{[0.003]}\end{array}$ & $\begin{array}{c}0.007 * * \\
{[0.003]}\end{array}$ & $\begin{array}{c}0.011 * * * \\
{[0.002]}\end{array}$ & $\begin{array}{c}0.011 * * * \\
{[0.002]}\end{array}$ \\
\hline Constant & $\begin{array}{c}-0,046 \\
{[0.073]}\end{array}$ & $\begin{array}{c}-0,059 \\
{[0.072]}\end{array}$ & $\begin{array}{l}0.107 * \\
{[0.053]}\end{array}$ & $\begin{array}{c}0,083 \\
{[0.110]}\end{array}$ \\
\hline Observations & 1054 & 1054 & 585 & 585 \\
\hline R-squared & 0,75 & 0,75 & 0,61 & 0,61 \\
\hline
\end{tabular}


TABLE 6 - Table 6 shows the regression analysis of the relationship between Entry Regulation and Response to Growth Opportunities. Growth measures are taken for the period 1981 to 1990. Growth_VA, Growth_No and Growth_Avsz represent industry growth rates of Value Added, Number of Establishments and Average Size. All regressions include country and industry dummies. $* * *, * *$ and $*$ represent coefficients significant at the $1 \%, 5 \%$, and $10 \%$ levels respectively. Standard errors in brackets.

\begin{tabular}{|c|c|c|c|c|c|c|}
\hline Model & (1) & (2) & (3) & (4) & (5) & (6) \\
\hline Sample & \multicolumn{3}{|c|}{ All Countries } & \multicolumn{3}{|c|}{ Rich Countries } \\
\hline Dep. Variable & Growth_VA & Growth_No & Growth_Avsz & Growth_VA & Growth_No & Growth_Avsz \\
\hline $\begin{array}{l}\text { USGrowth* } \\
\text { Entry_Reg }\end{array}$ & $\begin{array}{c}-0.014 \\
{[0.073]}\end{array}$ & $\begin{array}{c}-0.143 * * \\
{[0.068]}\end{array}$ & $\begin{array}{c}0.122 \\
{[0.089]}\end{array}$ & $\begin{array}{c}0.022 \\
{[0.072]}\end{array}$ & $\begin{array}{c}-0.195^{* * * *} \\
{[0.071]}\end{array}$ & $\begin{array}{c}0.221 * * \\
{[0.101]}\end{array}$ \\
\hline $\begin{array}{l}\text { USGrowth* } \\
\qquad \log (\text { GDPPC })\end{array}$ & $\begin{array}{c}0.018 \\
{[0.085]}\end{array}$ & $\begin{array}{c}0.041 \\
{[0.085]}\end{array}$ & $\begin{array}{c}-0.031 \\
{[0.099]}\end{array}$ & $\begin{array}{c}-0.013 \\
{[0.207]}\end{array}$ & $\begin{array}{c}-0.127 \\
{[0.202]}\end{array}$ & $\begin{array}{c}0.124 \\
{[0.289]}\end{array}$ \\
\hline Sector Share & $\begin{array}{c}0.458 * * * \\
{[0.069]}\end{array}$ & $\begin{array}{l}0.291 * * \\
{[0.113]}\end{array}$ & $\begin{array}{c}0.182 \\
{[0.120]}\end{array}$ & $\begin{array}{c}0.362^{* * * *} \\
{[0.081]}\end{array}$ & $\begin{array}{c}0.027 \\
{[0.063]}\end{array}$ & $\begin{array}{c}0.326^{* * * *} \\
{[0.060]}\end{array}$ \\
\hline Constant & $\begin{array}{c}0.08 \\
{[0.101]}\end{array}$ & $\begin{array}{c}0.013 \\
{[0.026]}\end{array}$ & $\begin{array}{c}0.031 \\
{[0.097]}\end{array}$ & $\begin{array}{c}0.122 \\
{[0.223]}\end{array}$ & $\begin{array}{c}0.134 \\
{[0.217]}\end{array}$ & $\begin{array}{l}-0.015 \\
{[0.304]}\end{array}$ \\
\hline Observations & 1012 & 906 & 870 & 543 & 477 & 477 \\
\hline
\end{tabular}


TABLE 7 - Table 7 presents instrumental variable results. The set of instruments includes a dummy for presidential political systems, a dummy for majoritarian voting structures, and dummies for legal origin, all interacted with USTurnover in models (1) - (4) and interacted with USGrowth in models (5) - (7). In all regressions, the sample is limited to countries with RICH=1. The same sets of controls are included as in the preceding regressions. All regressions include country and industry dummies. ***, ** and * represent coefficients significant at the $1 \%, 5 \%$, and $10 \%$ levels respectively. Standard errors in brackets.

\begin{tabular}{|c|c|c|c|c|c|c|c|}
\hline Model & (1) & $(2)$ & (3) & (4) & $(5)$ & $(6)$ & $(7)$ \\
\hline Dep. Variable & $\log ($ Avsz $)$ & $\log ($ Number $)$ & Sector Share & Margin & Growth(Avsz) & Growth(No) & Growth(VA) \\
\hline Turnover * & $0.56 * * *$ & $-1.10 * * *$ & $0.017 * *$ & 0.043 & & & \\
\hline Entry_Reg & [0.179] & [0.220] & [0.0078] & [0.028] & & & \\
\hline $\begin{array}{l}\text { USGrowth* } \\
\text { Entry_Reg }\end{array}$ & & & & & $\begin{array}{c}0.178 * * * \\
{[0.066]}\end{array}$ & $\begin{array}{c}-0.161 * * * \\
{[0.055]}\end{array}$ & $\begin{array}{c}0.020 \\
{[0.061]}\end{array}$ \\
\hline Observations & 419 & 419 & 478 & 2580 & 477 & 477 & 543 \\
\hline R-squared & 0.89 & 0.92 & 0.53 & 0.36 & 0.63 & 0.54 & 0.60 \\
\hline
\end{tabular}


Table 8 - Table 8 presents a summary of all previous regressions using Regulation of Labor. The sample is limited to countries with $\mathrm{RICH}=1$. The same sets of controls are included as in the preceding regressions. All regressions include country and industry dummies. $* * *, * *$ and $*$ represent coefficients significant at the $1 \%, 5 \%$, and $10 \%$ levels respectively. Standard errors in brackets.

\begin{tabular}{|c|c|c|c|c|c|c|}
\hline Model & (1) & $(2)$ & (3) & (4) & (5) & (6) \\
\hline Dep. Variable & $\log ($ Avsz $)$ & Log(Number) & Margin & Growth_VA & Growth_No & Growth_Avsz \\
\hline Turnover * & -0.315 & -0.968 & 0.057 & & & \\
\hline Labor_reg & [0.612] & [0.596] & [0.040] & & & \\
\hline USGrowth * & & & & 0.072 & -0.343 & 0.356 \\
\hline Labor_reg & & & & [0.190] & {$[0.230]$} & [0.331] \\
\hline Observations & 419 & 419 & 2058 & 543 & 477 & 477 \\
\hline R-squared & 0.88 & 0.92 & 0.18 & 0.6 & 0.53 & 0.62 \\
\hline
\end{tabular}




\section{APPENDIX}

TABLE AP1 - Table AP1 presents a robustness checks. Average Employment represents the ratio of industry Employees to industry Number of Establishments. The sample is limited to countries with RICH=1. The same sets of controls are included as in the preceding regressions. All regressions include country and industry dummies. $* * * * *$ and $*$ represent coefficients significant at the $1 \%, 5 \%$, and $10 \%$ levels respectively. Standard errors in brackets.

\begin{tabular}{l|cc}
\hline \hline \multicolumn{1}{c|}{ Model } & $(\mathbf{1})$ & (2) \\
\hline Dep. Variable & Log(Avemp) & Gwth_Avemp \\
\hline Turnover* & $0.558^{* *}$ & \\
Entry_Reg & {$[0.232]$} & \\
& & \\
USGrowth* & & $0.174^{* *}$ \\
$\quad$ Entry_Reg & & {$[0.083]$} \\
Observations & 419 & 477 \\
R-squared & 0.8 & 0.45 \\
\hline \hline
\end{tabular}


Table AP2 - Table AP2 shows the regression analysis of the relationship between Entry Regulation and Industry Structure, using "USEntry" rate instead of "USTurnover" rate as a proxy (inverse) of natural entry barriers. Avsz represents the Firm Average Size measured as the ratio of Industry Value Added to Industry Number of Establishments and Number measures the Industry Number of Establishments. The sample is limited to countries with $\mathrm{RICH}=1$. The same sets of controls are included as in the preceding regressions. All regressions include country and industry dummies. $* * *, * *$ and $*$ represent coefficients significant at the $1 \%, 5 \%$, and $10 \%$ levels respectively. Standard errors in brackets.

\begin{tabular}{|c|c|c|c|c|c|c|c|c|}
\hline $\begin{array}{c}\text { Model } \\
\text { Dep. Variable }\end{array}$ & $\begin{array}{c}1 \\
\log (\text { Avsz }) \\
\end{array}$ & $\begin{array}{c}2 \\
\log (\text { Number }) \\
\end{array}$ & $\begin{array}{c}3 \\
\log (\text { Avsz }) \\
\end{array}$ & $\begin{array}{c}4 \\
\log (\text { Number }) \\
\end{array}$ & $\begin{array}{c}5 \\
\text { Sector Share } \\
\end{array}$ & $\begin{array}{c}6 \\
\text { Sector Share } \\
\end{array}$ & $\begin{array}{c}7 \\
\text { Margin } \\
\end{array}$ & $\begin{array}{c}8 \\
\text { Margin } \\
\end{array}$ \\
\hline $\begin{array}{l}\text { Entry * } \\
\quad \text { Entry Reg }\end{array}$ & $\begin{array}{c}1.096 * * * \\
{[0.263]}\end{array}$ & $\begin{array}{c}-1.912 * * * \\
{[0.286]}\end{array}$ & $\begin{array}{c}1.074 * * * \\
{[0.218]}\end{array}$ & $\begin{array}{c}-1.414 * * * \\
{[0.298]}\end{array}$ & $\begin{array}{c}-0.009 \\
{[0.014]}\end{array}$ & $\begin{array}{c}0.005 \\
{[0.014]}\end{array}$ & $\begin{array}{c}0.0184 * * \\
{[0.008]}\end{array}$ & $\begin{array}{c}0.0213 * * \\
{[0.008]}\end{array}$ \\
\hline $\begin{array}{l}\text { Entry * } \\
\text { GDPPC }\end{array}$ & & & $\begin{array}{c}-0.111 \\
{[0.783]}\end{array}$ & $\begin{array}{l}2.529 * * \\
{[1.096]}\end{array}$ & & $\begin{array}{c}0.079 * * * \\
{[0.027]}\end{array}$ & & $\begin{array}{c}0.0780 * \\
{[0.041]}\end{array}$ \\
\hline $\begin{array}{l}\text { Observations } \\
\text { R-squared }\end{array}$ & $\begin{array}{l}404 \\
089\end{array}$ & $\begin{array}{l}404 \\
093\end{array}$ & $\begin{array}{l}404 \\
089\end{array}$ & $\begin{array}{l}404 \\
0.93\end{array}$ & $\begin{array}{l}460 \\
0.53\end{array}$ & $\begin{array}{l}460 \\
0.54\end{array}$ & $\begin{array}{l}2058 \\
0.18\end{array}$ & $\begin{array}{l}2058 \\
0.18\end{array}$ \\
\hline
\end{tabular}


Figure 1 - Figure 1 summarizes the differential response to entry regulation. The vertical line shows the median entry regulation.
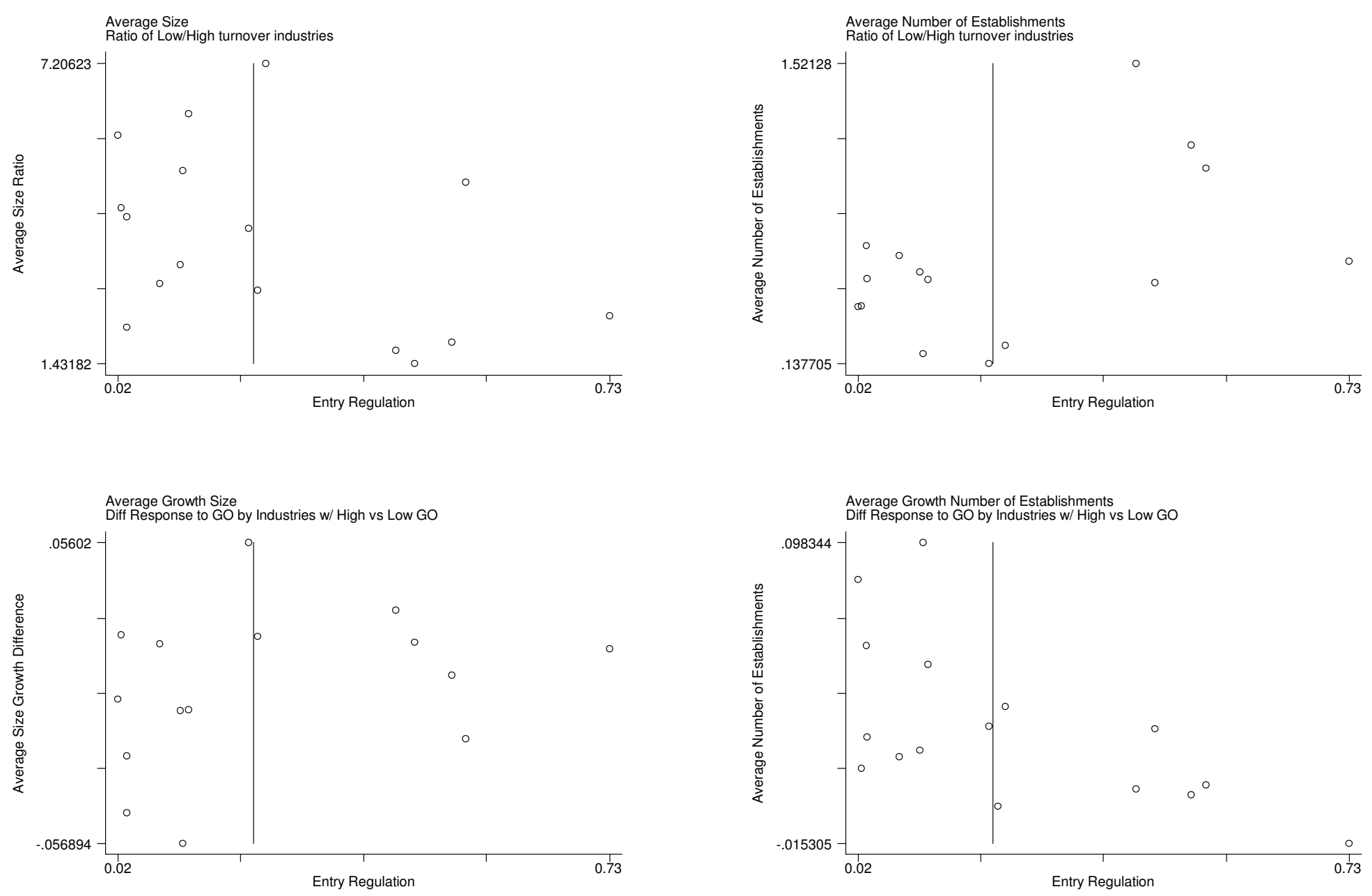